\title{
Assessment of Physicochemical Quality, Antioxidant Content and Activity, and Inhibition of Cholinesterase between Unripe and Ripe Blueberry Fruit
}

\author{
Hyesung Hwang ${ }^{1}$, Young-Jun Kim ${ }^{2, *(D)}$ and Youngjae Shin ${ }^{3, *(D)}$ \\ 1 Department of Environmental Horticulture, Dankook University, Cheonan, Chungnam 31116, Korea; \\ sug7764@hanmail.net \\ 2 Department of Food Science and Technology, Seoul National University of Science and Technology, \\ Seoul 01811, Korea \\ 3 Department of Food Engineering, Dankook University, Cheonan, Chungnam 31116, Korea \\ * Correspondence: kimyj@seoultech.ac.kr (Y.-J.K.); ys234@dankook.ac.kr (Y.S.); Tel.: +82-41-550-3562 (Y.S.)
}

Received: 3 May 2020; Accepted: 25 May 2020; Published: 26 May 2020

\begin{abstract}
Five Korean blueberries ("Nelson", "Duke ", "Bluejay ", "Toro", and "Elliot ") were harvested at two maturity stages (unripe and ripe) to evaluate fruit quality and antioxidant activities. The Hunter L, a, and b color of ripe blueberries was lower than that of unripe fruit. Soluble solid concentration (SSC) and $\mathrm{pH}$ increased, and titratable acidity (TA) and firmness decreased as the blueberries matured. The ripe blueberry fruits showed a higher SSC/TA ratio than the unripe fruits. Although total anthocyanin, flavonoids, phenolics content, and antioxidant activity were higher in ripe blueberries than in unripe fruit, the unripe fruit had higher acetylcholinesterase (AChE) and butyrylcholinesterase (BChE) inhibition activities than ripe fruit in all cultivars. Total antioxidant activity was highly correlated with total flavonoids and phenolics. The relationships between the total antioxidant activity and the $\mathrm{AChE}$ or $\mathrm{BChE}$ inhibitory activity are negative. There were several physicochemical quality and antioxidant activity differences in blueberries, depending on the cultivar and the maturity at harvest. Unripe fruits also contain potential health-promoting bioactive compounds as functional food ingredients.
\end{abstract}

Keywords: blueberry; cultivar; maturity; antioxidant; acetylcholinesterase; butyrylcholinesterase

\section{Introduction}

Fruits and vegetables contain many different phytochemicals [1,2]. Many studies have reported the higher intake of fruits and vegetables can reduce the risk of developing chronic disease [3,4]. Berries contain many bioactive compounds and are reported to have high antioxidant [5], antitumor [6,7] and anti-inflammatory activities [8]. Among the various berries such as blueberries, strawberries, blackberries, and cranberries are consumed not only in raw form but also in the form of beverages, yoghurt, jelly, and jam as processed foods. In many in vitro and in vivo experiments, berries are known to reduce the risk of cancer because they contain abundant amounts of phenolic acid, flavonoids, tannins, stilbenes, vitamin C, and vitamin E [6,7,9].

Blueberries (Vaccinium spp.) are classified into three types, namely the low-bush, high-bush, and rabbit-eye blueberries [10]. Low-bush blueberries are wild blueberries native to the northeast of the United States and Canada. These blueberries grow to about $15-30 \mathrm{~cm}$ in height; the fruit are harvested between July and September and are mainly used as raw fruit or are processed as frozen or canned fruit. High-bush blueberries are mainly grown in Florida and southern Michigan in the US as 
well as in eastern Canada. Their average height is about $2-3 \mathrm{~m}$. Rabbit-eye blueberries are native to southeastern US and are grown in warmer winters as they have less cold hardiness [10,11].

Studies comparing the physicochemical qualities and antioxidant activities of blueberries have been conducted according to cultivar, harvest maturity, and storage period [12-14]. In Korea, the chemical composition of blueberries and the analysis of antioxidant contents and activities have also been reported [11,15]. Antioxidants inhibit the lipid oxidation induced by free radicals in the human body and are highly regarded as physiologically active substances that prevent carcinogenesis and aging by preventing chronic diseases, such as hypertension and diabetes. They also reduce the levels of reactive oxygen species (ROS) by preventing inflammation, cancer, and aging [9]. According to Singh et al. [16], ROS cause neurodegenerative diseases in the human brain. Dementia can be classified as cerebrovascular dementia and Alzheimer's type dementia. Alzheimer's disease (AD) is known to result from a decrease in the levels of the neurotransmitter, acetylcholine [17]. Despite numerous research efforts, the cause of AD is not fully understood. Acetylcholinesterase (AChE) is a key enzyme that hydrolyses acetylcholine to choline and acetic acid. Therefore, the inhibition of AChE has emerged as a commonly used treatment against AD. Treatment via the inhibition of AChE and butyrylcholinesterase (BChE) temporarily increases the levels of acetylcholine, which is important for memory [18].

The antioxidative effects of polyphenols in plants are expected to have a potential effect on the improvement of memory loss in AD [17-19]. In addition, studies on the cholinesterase inhibitory activity of fruits and vegetables grown in Korea are insufficient, and there is a lack of data of comparative analysis of the antioxidants in blueberries according to the cultivar and maturity stage at harvest. Therefore, the objective of this study was to compare the antioxidant contents, activities, and cholinesterase inhibitory activity according to the maturity stage and cultivar of blueberries.

\section{Materials and Methods}

\subsection{Experimental Materials and Reagents}

The blueberries used in the present study consisted of five cultivars, "Nelson", "Toro", "Duke", "Bluejay", and "Elliot" from a farm in Cheonan, Chungnam-Province. Both the unripe (50\% of fruit surface turns into purple color) and ripe (100\% of fruit surface turns into dark purple color) fruits were harvested. All fruit used in the experiment had a uniform size. Folin-Ciocalteu's phenol reagent, 2,2-diphenyl-1-picrylhydrazyl (DPPH), 2,2-azino-bis(3-ethylbenzothiazoline-6-sulfonic acid) (ABTS), sodium nitrite, aluminum chloride hexahydrate, (+)-catechin, gallic acid monohydrate reagent, potassium chloride, sodium acetate anhydrous, hydrochloric acid, and sodium carbonate anhydrous were purchased from Sigma (St. Louis, MO, USA). Other reagents used were of analytical grade.

\subsection{Evaluation of Blueberry Physicochemical Qualities}

The Hunter Lab values were measured using a color meter (Chroma Meter CR-400, Minolta, Tokyo, Japan) to assess fruit color change. The color of the fruits was represented as $\mathrm{L}$ value (lightness ranging from $0=$ black to $100=$ white), a value (redness), and $b$ value (yellowness). Thirty berries from each cultivar were measured, and the mean value was calculated. The readings were taken around the equatorial region of each berry. Fruit firmness was measured using a fruit hardness tester (FHM-1, Takemura Co., Tokyo, Japan), where the maximum resistance was measured at the moment when the 5.0-mm diameter probe penetrated the fruit from the side; it is expressed in Newton (N). The soluble solids content (SSC) of the fruit was measured by grinding the whole fruit in a commercial blender (HR20011, Phillips, Carson, NV, USA). The SSC was measured three times using a digital glucose refractometer (PAL-1, Atago, Tokyo, Japan) [5]. Titratable acidity (TA) was determined by mixing $2 \mathrm{~g}$ of the ground sample with $200 \mathrm{~mL}$ of distilled water and performing a neutralization titration with $0.1 \mathrm{~N} \mathrm{NaOH}$ and $2-4$ drops of $1 \%$ phenolphthalein solution. The $\mathrm{pH}$ was measured using a $\mathrm{pH}$ meter (Starter300, Ohaus Co., Ltd., Parsippany, NJ, USA). 


\subsection{Blueberry Organic Acid Content}

Organic acids were analyzed using the method by Kim and Shin [20] with some modifications. For individual organic acid analysis, the Agilent 1100 Series with a diode array detector was used. The extract was diluted 10-fold with distilled water, and the samples were filtered through a $0.2-\mu \mathrm{m}$ syringe. A Prevail organic acid column $\left(250 \times 4.6 \mathrm{~mm}\right.$ id., $5 \mu \mathrm{m}$, Alltech, Deerfield, IL, USA) was used at $25^{\circ} \mathrm{C}$. The high-performance liquid chromatography (HPLC) mobile phase was $25 \mathrm{mM} \mathrm{KH}_{2} \mathrm{PO}_{4}$ adjusted to $\mathrm{pH} 2.1 \mathrm{using} \mathrm{H}_{3} \mathrm{PO}_{4}$, and the diode array detector was positioned at $210 \mathrm{~nm}$ with a $1.0 \mathrm{~mL} / \mathrm{min}$ flow rate. An injection volume of $10 \mu \mathrm{L}$ was used for the analysis. For the calibration curve, three different points $(4,20$, and $100 \mathrm{mg} / 100 \mathrm{~g}$ ) were obtained with the standard solution (oxalic acid, tartaric acid, malic acid, lactic acid, acetic acid, citric acid, succinic acid, and fumaric acid), and the results are expressed as $\mathrm{mg} / 100 \mathrm{~g}$ of fresh weight (FW).

\subsection{Blueberry Sugar Content}

The quantification of sugars was performed using the method described by Kim and Shin [20] with some modifications. After the blueberry extract was diluted 10-fold with distilled water, the sample was filtered through a $0.45-\mu \mathrm{m}$ syringe filter to perform HPLC analysis. Multiple HPLC analyses were performed using the Agilent 1200 series with a Refractive Index (RI) detector. For the separation of individual sugars, a carbohydrate high-performance column $(250 \times 4.6 \mathrm{~mm}$ i.d., $4 \mu \mathrm{m}$, Waters, Milford, MA, USA) was used at $30^{\circ} \mathrm{C}$. The mobile phase was $81 \%$ acetonitrile in distilled water at a flow rate of $1.0 \mathrm{~mL} / \mathrm{min}$. The injection amount was $10 \mu \mathrm{L}$. Sugar standards (glucose, fructose, sucrose, and maltose) were purchased from Sigma (St. Louis, USA). The calibration curves for three different points (200, 500 , and $1000 \mathrm{mg} / 100 \mathrm{~g}$ ) were obtained using standard solutions, and the results are expressed as $\mathrm{mg} / 100 \mathrm{~g} \mathrm{FW}$.

\subsection{Blueberry Extraction for the Measurement of Antioxidant and AChE and BChE Inhibitory Activity}

The blueberries were sliced and frozen with liquid nitrogen for use in the experiment. After adding $80 \%$ ethanol to $40 \mathrm{~g}$ of frozen blueberries, a commercial blender (HR20011, Philips, Carson, NV, USA) was used to homogenize the berries for $3 \mathrm{~min}$. The homogenized solution was filtered through a Whatman \#1 paper filter, and the filtered solution was concentrated in a rotary evaporator $(\mathrm{N}-1000$, Eyela, Tokyo, Japan) at $45^{\circ} \mathrm{C}$ [5]. The concentrated extractions were stored at $-20{ }^{\circ} \mathrm{C}$ and used for the measurement of total anthocyanin content, total flavonoid content, total phenolic content, total antioxidant activity, and $\mathrm{AChE}$ and $\mathrm{BChE}$ inhibitory activities.

\subsection{Blueberry Total Anthocyanin Analysis}

The $\mathrm{pH}$ differential method was used for total anthocyanin analysis [21]. The extracted samples were diluted 10-fold with $\mathrm{pH} 1.0$ buffer and 10-fold with $\mathrm{pH} 4.5$ buffer, and the absorbance at 510 and $700 \mathrm{~nm}$ was measured using a spectrophotometer (Optizen POP, Mecasys, Daejeon, Korea). The total anthocyanin content was calculated using the following equation and expressed as $\mathrm{mg}$ cyanidin 3-glucoside equivalents (CGE)/100 g FW.

Total anthocyanin content $(\mathrm{mg}$ CGE $/ 100 \mathrm{~g} \mathrm{FW})=\frac{(\mathrm{A} \times \mathrm{MW} \times \mathrm{D} \times 1000)}{\varepsilon}$

$\mathrm{A}($ absorbance value $)=\left[(\mathrm{A} 510 \mathrm{~nm}-\mathrm{A} 700 \mathrm{~nm})_{\mathrm{pH} 1.0}-(\mathrm{A} 510 \mathrm{~nm}-\mathrm{A} 700 \mathrm{~nm})_{\mathrm{pH} 4.5}\right]$

MW (cyanidin 3-glucoside molecular weight) $=449.2$

$\mathrm{D}$ (dilution factor $)=$ dilution factor

$\varepsilon$ (cyanidin 3-glucoside molar extinction coefficient) $=26,900$

\subsection{Blueberry Total Flavonoid Analysis}

Total flavonoid content was measured by colorimetric analysis [22,23]. To a $15-\mathrm{mL}$ test tube containing $4 \mathrm{~mL}$ of distilled water and $1 \mathrm{~mL}$ of blueberry extract, we added $0.3 \mathrm{~mL}$ of $5 \% \mathrm{NaNO}_{2}$. The mixture was vortexed and left for $5 \mathrm{~min}$ at room temperature. Then, $0.3 \mathrm{~mL}$ of $10 \% \mathrm{AlCl}_{3}$ was 
added and the mixture was vortexed and left at room temperature for $6 \mathrm{~min}$. After $2.4 \mathrm{~mL}$ of distilled water was added to $2 \mathrm{~mL}$ of $1 \mathrm{~N} \mathrm{NaOH}$, the mixture was vortexed and the final volume was adjusted to $10 \mathrm{~mL}$; then, the absorbance at $510 \mathrm{~nm}$ was measured. Catechin was used as a standard, and the results are expressed in $\mathrm{mg}$ catechin equivalents (CE)/100 g FW.

\subsection{Blueberry Total Phenolic Analysis}

Total phenolic content was measured using the Folin-Ciocalteu colorimetric method [22,24]. After adding $0.2 \mathrm{~mL}$ of blueberry extract to a $15-\mathrm{mL}$ test tube containing $2.6 \mathrm{~mL}$ of deionized water, $0.2 \mathrm{~mL}$ of Folin-Ciocalteu reagent was added and the mixture was vortexed and left at room temperature for $6 \mathrm{~min}$. Then, $2 \mathrm{~mL}$ of $7 \% \mathrm{Na}_{2} \mathrm{CO}_{3}$ was added and the mixture was left for $90 \mathrm{~min}$ in a dark room; finally, the absorbance was measured at $750 \mathrm{~nm}$. Gallic acid was used as a standard, and the results are expressed in mg gallic acid equivalent (GAE)/100 g FW.

\subsection{Blueberry DPPH Radical Scavenging Activity Analysis}

The DPPH radical scavenging activity was measured using a modified method described by Mira-Sánchez et al. [25]. The DPPH solution was prepared by dissolving $0.00789 \mathrm{~g}$ powdered DPPH in $200 \mathrm{~mL}$ methanol. The solution was diluted to an optical density (OD) value of 0.65 at $517 \mathrm{~nm}$ using $80 \%$ methanol. After adding $2.95 \mathrm{~mL}$ of DPPH solution to $50 \mu \mathrm{L}$ of the blueberry extract, the mixture was left for $30 \mathrm{~min}$ in a dark room; then, the absorbance was measured at $517 \mathrm{~nm}$. Antioxidant activity by DPPH radical scavenging activity is expressed as mg vitamin C equivalent (VCE)/100 g FW.

\subsection{Blueberry ABTS Radical Scavenging Activity Analysis}

The ABTS radical scavenging activity of the extracted samples was measured using ABTS

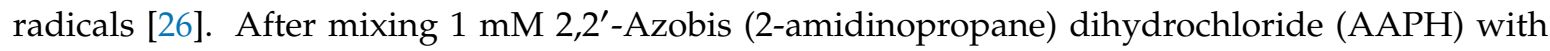
$100 \mathrm{~mL}$ of $1 \times$ phosphate buffer saline (PBS) solution and $2.5 \mathrm{mM}$ ABTS, the mixture was allowed to react for $40 \mathrm{~min}$ in a $70{ }^{\circ} \mathrm{C}$ water bath. Subsequently, the PBS solution was used to dilute the mixture to an OD value of 0.65 at $734 \mathrm{~nm}$. The test solution containing $20 \mu \mathrm{L}$ of the diluted solution mixed with deionized water and $980 \mu \mathrm{L}$ of the ABTS reaction solution was reacted at $37^{\circ} \mathrm{C}$ for $10 \mathrm{~min}$. Then, the absorbance was measured at $734 \mathrm{~nm}$. The results are expressed in $\mathrm{mg}$ vitamin $\mathrm{C}$ equivalents (VCE)/100 g FW.

\subsection{Blueberry AChE and BChE Inhibitory Activity Analysis}

AChE inhibitory activity was measured using the Ellman colorimetric method in 96-well microplate [27]. For the enzymatic reaction, $150 \mu \mathrm{L}$ of PBS was dispensed, followed by reaction with blueberry fruit extract $(10 \mathrm{mg} / \mathrm{mL})$ and $20 \mu \mathrm{L}$ of $0.2 \mathrm{U}$ AChE. Subsequently, $30 \mu \mathrm{L}$ of 5,5-dithio-bis (2-nitrobenzoic acid) and $20 \mu \mathrm{L}$ of $15 \mathrm{mM}$ acetylthiocholine iodide were added and allowed to react for $30 \mathrm{~min}$ at $37^{\circ} \mathrm{C}$. Then, the absorbance was measured at $415 \mathrm{~nm}$ using a microplate reader (Versa max, Molecular Devices, Sunnyvale, CA, USA). Tacrine was used as a positive control, and the results are expressed as the inhibition rate (\%). The BChE inhibitory activity was also measured using a modified Ellman's method [27]. Tacrine was used as the positive control, and the results are also expressed as the inhibition rate $(\%)$.

Cholinesterase inhibitory activity $(\%)=(1-$ absorbance of sample or positive control/absorbance of negative control) $\times 100$

\subsection{Statistical Analysis}

For statistical analysis, analysis of variance (ANOVA) was performed using SAS version 9.3 (SAS Institute, Inc., Cary, NC, USA), and significant differences in the results were expressed in confidence intervals of 95\% using Duncan's multiple range test. Pearson correlations were used to quantify 
the relationships between parameters. The data are expressed as the mean \pm standard deviation for triplicate determinations.

\section{Results and Discussion}

\subsection{Blueberry Color}

The Hunter $\mathrm{L}$, $\mathrm{a}$, and $\mathrm{b}$ color of five different blueberry cultivars at different maturity stages are shown in Table 1. The average $L$ value of blueberries was 34.80 for the unripe fruit and 25.85 for the ripe fruit. As the fruit ripened, both the $\mathrm{L}, \mathrm{a}$, and $\mathrm{b}$ values decreased because the fruit color was turned to dark purple from red. Therefore, the Hunter $a$ and $b$ values showed a tendency to decrease from $a$ positive value to negative in all three cultivars. The "Nelson", "Toro", "Duke", "Bluejay", and "Elliot" unripe fruit showed significantly higher Hunter $b$ values than the values for the ripe fruit.

Table 1. Hunter $\mathrm{L}$, a, b color of blueberry fruits at different maturity stages.

\begin{tabular}{ccccc}
\hline Cultivars & Maturity Stages & $\begin{array}{c}\text { Hunter L } \\
\text { (Lightness) }\end{array}$ & $\begin{array}{c}\text { Hunter a } \\
\text { (Redness) }\end{array}$ & $\begin{array}{c}\text { Hunter b } \\
\text { (Yellowness) }\end{array}$ \\
\hline \multirow{2}{*}{ Nelson } & Unripe & $36.19 \pm 5.12^{\mathrm{b}}$ & $7.65 \pm 3.04^{\mathrm{bc}}$ & $3.11 \pm 3.69^{\mathrm{b}}$ \\
& Ripe & $24.15 \pm 1.45^{\mathrm{f}}$ & $-0.04 \pm 0.34^{\mathrm{d}}$ & $-2.04 \pm 0.80^{\mathrm{d}}$ \\
\hline \multirow{2}{*}{ Toro } & Unripe & $33.43 \pm 2.89^{\mathrm{c}}$ & $10.84 \pm 2.62^{\mathrm{a}}$ & $2.29 \pm 2.21^{\mathrm{bc}}$ \\
& Ripe & $26.30 \pm 1.05^{\mathrm{de}}$ & $-0.21 \pm 0.14^{\mathrm{d}}$ & $-3.08 \pm 0.44^{\mathrm{de}}$ \\
\hline \multirow{2}{*}{ Duke } & Unripe & $34.11 \pm 2.95^{\mathrm{c}}$ & $8.31 \pm 2.39^{\mathrm{b}}$ & $2.42 \pm 2.46^{\mathrm{bc}}$ \\
& Ripe & $26.17 \pm 1.03^{\mathrm{de}}$ & $-0.25 \pm 0.08^{\mathrm{d}}$ & $-2.89 \pm 0.65^{\mathrm{de}}$ \\
\hline \multirow{2}{*}{ Bluejay } & Unripe & $37.68 \pm 4.67^{\mathrm{a}}$ & $7.01 \pm 3.82^{\mathrm{c}}$ & $6.01 \pm 2.71^{\mathrm{a}}$ \\
& Ripe & $27.15 \pm 1.65^{\mathrm{d}}$ & $-0.13 \pm 0.21^{\mathrm{d}}$ & $-3.38 \pm 0.60^{\mathrm{e}}$ \\
\hline \multirow{2}{*}{ Elliot } & Unripe & $32.60 \pm 3.33^{\mathrm{c}}$ & $8.46 \pm 2.22^{\mathrm{b}}$ & $1.78 \pm 2.06^{\mathrm{c}}$ \\
& Ripe & $25.46 \pm 1.24^{\text {ef }}$ & $0.17 \pm 0.33^{\mathrm{d}}$ & $-2.75 \pm 0.70^{\mathrm{de}}$ \\
\hline
\end{tabular}

Date are means \pm standard deviation. ${ }^{\mathrm{a}-\mathrm{f}}$ Values in the same column not sharing a common superscript are significantly different by Duncan's multiple range test $(p<0.05)$.

\subsection{Blueberry Firmness}

The average firmness of unripe fruit $(6.80 \mathrm{~N})$ was higher than that of ripe fruit $(4.88 \mathrm{~N})$ by $1.92 \mathrm{~N}$. The firmness of unripe "Duke" was $7.15 \pm 0.42 \mathrm{~N}$ and was significantly higher than that of the other cultivars. The ripe "Nelson" was $4.25 \pm 0.79$, the lowest compared to the other cultivars (Table 2). Shin et al. [5] also found that unripe strawberries are about twice as hard as the ripe fruit. The low firmness of the ripe fruit is due to the softening of the fruit, which is caused by the collapse of the cell walls of the fruit and the weakening of cell binding. It is known that various cell wall-degrading enzymes work in this process [28].

Table 2. Firmness, Soluble solid content, titratable acidity, and $\mathrm{pH}$ of blueberry fruits at different maturity stages.

\begin{tabular}{|c|c|c|c|c|c|c|}
\hline Cultivars & $\begin{array}{l}\text { Maturity } \\
\text { Stages }\end{array}$ & $\begin{array}{l}\text { Firmness } \\
(\mathrm{N} / 5 \mathrm{~mm} \varnothing)\end{array}$ & $\begin{array}{c}\text { Soluble Solid } \\
\text { Concentration } \\
\left({ }^{\circ} \text { Brix }\right)\end{array}$ & $\begin{array}{c}\text { Titratable } \\
\text { Acidity } \\
(\%)\end{array}$ & $\begin{array}{c}\text { SSC/TA } \\
\text { Ratio }\end{array}$ & $\mathrm{pH}$ \\
\hline \multirow{2}{*}{ Nelson } & Unripe & $6.71 \pm 0.69 b c$ & $10.23 \pm 0.06^{c}$ & $2.20 \pm 0.03^{b}$ & 4.65 & $2.66 \pm 0.01^{f}$ \\
\hline & Ripe & $4.25 \pm 0.79^{\mathrm{f}}$ & $12.67 \pm 0.15^{\mathrm{a}}$ & $0.77 \pm 0.02^{\mathrm{f}}$ & 16.45 & $3.12 \pm 0.02^{c}$ \\
\hline \multirow{2}{*}{ Toro } & Unripe & $6.87 \pm 0.57 \mathrm{ab}$ & $8.53 \pm 0.15^{f}$ & $2.08 \pm 0.02^{c}$ & 4.10 & $2.62 \pm 0.01 \mathrm{fg}$ \\
\hline & Ripe & $5.38 \pm 0.54^{\mathrm{d}}$ & $10.30 \pm 0.10^{c}$ & $0.64 \pm 0.01^{g}$ & 16.09 & $3.07 \pm 0.04^{d}$ \\
\hline \multirow{2}{*}{ Duke } & Unripe & $7.15 \pm 0.42^{a}$ & $7.93 \pm 0.25^{g}$ & $1.90 \pm 0.03^{\mathrm{d}}$ & 4.17 & $2.60 \pm 0.01^{g}$ \\
\hline & Ripe & $5.09 \pm 0.58^{\mathrm{de}}$ & $10.27 \pm 0.15^{c}$ & $0.46 \pm 0.01^{h}$ & 22.33 & $3.31 \pm 0.02^{\mathrm{a}}$ \\
\hline \multirow{2}{*}{ Bluejay } & Unripe & $6.78 \pm 0.51 \mathrm{bc}$ & $9.57 \pm 0.06^{\mathrm{e}}$ & $2.39 \pm 0.03^{a}$ & 4.00 & $2.64 \pm 0.02^{\mathrm{fg}}$ \\
\hline & Ripe & $4.78 \pm 0.69^{\mathrm{e}}$ & $12.87 \pm 0.15^{\mathrm{a}}$ & $0.66 \pm 0.01 \mathrm{~g}$ & 19.50 & $3.26 \pm 0.05^{b}$ \\
\hline \multirow{2}{*}{ Elliot } & Unripe & $6.51 \pm 0.82^{c}$ & $9.87 \pm 0.06^{\mathrm{d}}$ & $2.10 \pm 0.01^{c}$ & 4.70 & $2.66 \pm 0.01^{f}$ \\
\hline & Ripe & $4.91 \pm 0.61^{\mathrm{e}}$ & $11.53 \pm 0.06^{b}$ & $1.07 \pm 0.02^{\mathrm{e}}$ & 10.78 & $2.85 \pm 0.04^{\mathrm{e}}$ \\
\hline
\end{tabular}

Date are means \pm standard deviation. ${ }^{a-g}$ Values in the same column not sharing a common superscript are significantly different by Duncan's multiple range test $(p<0.05)$. SSC/TA ratio is calculated by SSC $\left({ }^{\circ}\right.$ Brix $) /$ titratable acidity $(\%)$. 


\subsection{Blueberry SSC, TA, and $p H$}

SSC and TA are important sensory factors that affect the taste of fruits. The average SSC of unripe and ripe fruit was $9.23^{\circ} \mathrm{Bx}$ and $11.53^{\circ} \mathrm{Bx}$, respectively. Overall, ripe fruit showed a higher SSC than unripe fruit (Table 2). The SSC of ripe "Bluejay" and "Nelson" cultivars were $12.87 \pm 0.15^{\circ} \mathrm{Bx}$ and $12.67 \pm 0.15^{\circ} \mathrm{Bx}$, respectively, which were significantly higher than that of the other cultivars. The SSC of unripe "Duke" showed the lowest SSC at $7.93 \pm 0.25^{\circ} \mathrm{Bx}$. Unripe fruit showed a higher TA than ripe fruit. The TA of unripe "Nelson" and "Bluejay" were $2.20 \% \pm 0.03 \%$ and $2.39 \% \pm 0.03 \%$, whereas the TA of ripe "Duke" was $0.46 \% \pm 0.01 \%$, which was the lowest among the samples (Table 2). For $\mathrm{pH}$, ripe fruit had a higher $\mathrm{pH}$ than unripe fruit, with an average of 3.12 and 2.64, respectively (Table 2).

\subsection{Blueberry Organic Acid Content}

In contrast to SSC, the TA consistently decreased as the blueberries matured (Table 2). Analysis of organic acids showed that citric acid was dominant in all cultivars (Figure 1). Total organic acid content was significantly higher in unripe than ripe blueberry. The organic acid content is highly associated with the acidity of blueberries and is also closely related to their taste. The citric acid and malic acid content decreased as the blueberries matured in all cultivars (Figure 1). Previous studies showed that the main organic acid in blueberry was citric acid, which makes up $77 \%-87 \%$ of the total acid, depending on the maturity stage at harvest. In addition, small amounts of succinic, tartaric, and shikimic acids were found [29]. A decrease in citric acid was reported in ripening blueberry fruit $[29,30]$. In our study, the citric acid content of the "Bluejay" cultivar was significantly higher in unripe fruit than in the other cultivars.

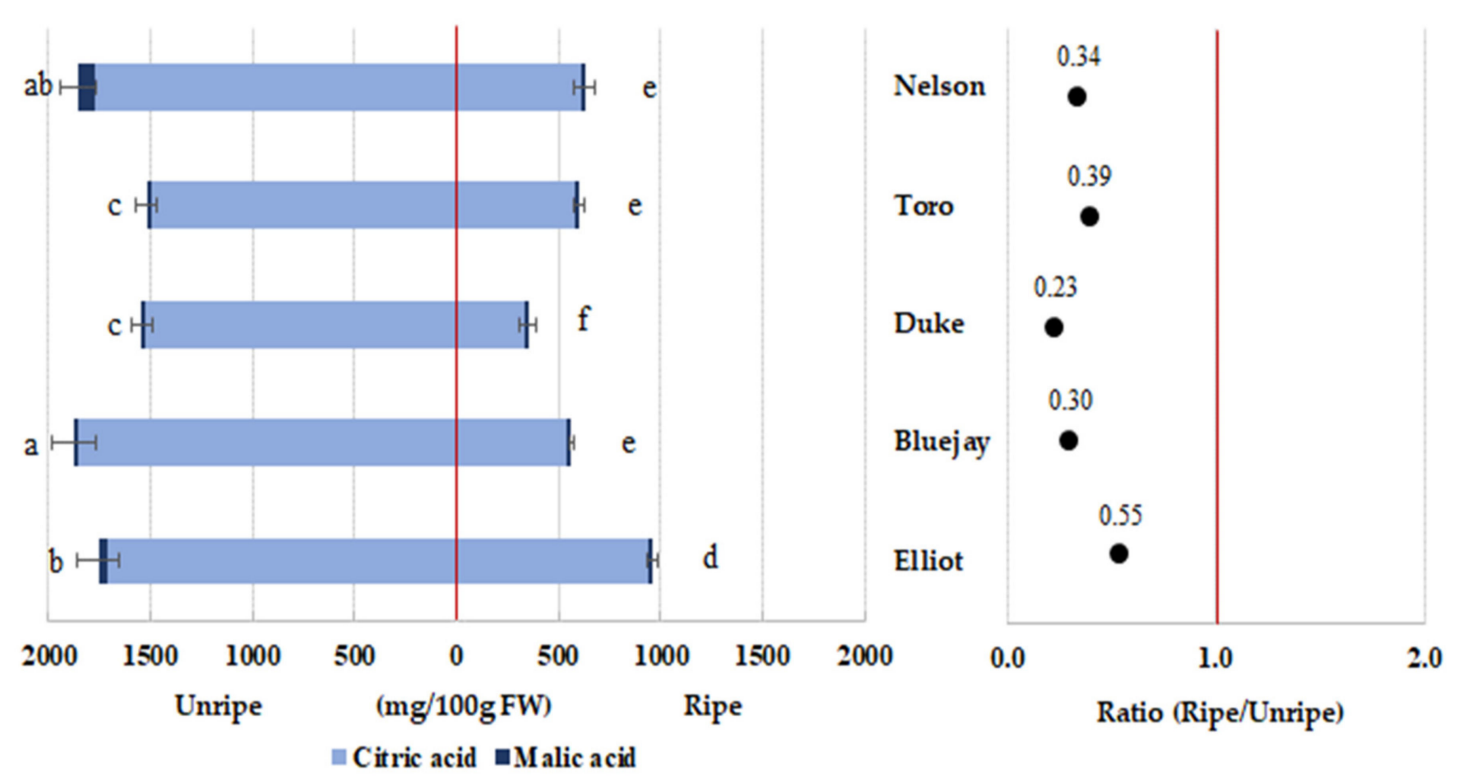

Figure 1. Different letters (a-f) are significant differences by Duncan's multiple range test $(p<0.05)$.

\subsection{Blueberry Sugar Content}

Sugars (sucrose, glucose, and fructose) are related to the sweetness of fruit, whereas organic acids (citrate and malate) determine fruit acidity. The quantification of individual sugars (fructose, glucose, and sucrose) was analyzed in the different cultivars and maturities. Fructose and glucose were the main sugars in all blueberry cultivars, and sugar content increased as blueberries matured in all cultivars. The total sugar content of the "Bluejay" and "Nelson" cultivars at the ripe stage was significantly higher (10.18 and $9.36 \mathrm{~g} / 100 \mathrm{~g} \mathrm{FW}$, respectively) than that of the other cultivars (Figure 2). Li et al. [30] reported that the three major sugars of high-bush blueberries are sucrose, 
fructose, and glucose. The latter two contained similar amounts and were predominant in blueberry fruit, whereas sucrose was present in relatively low concentrations; these two sugars increased during fruit maturation, which is in agreement with our results.

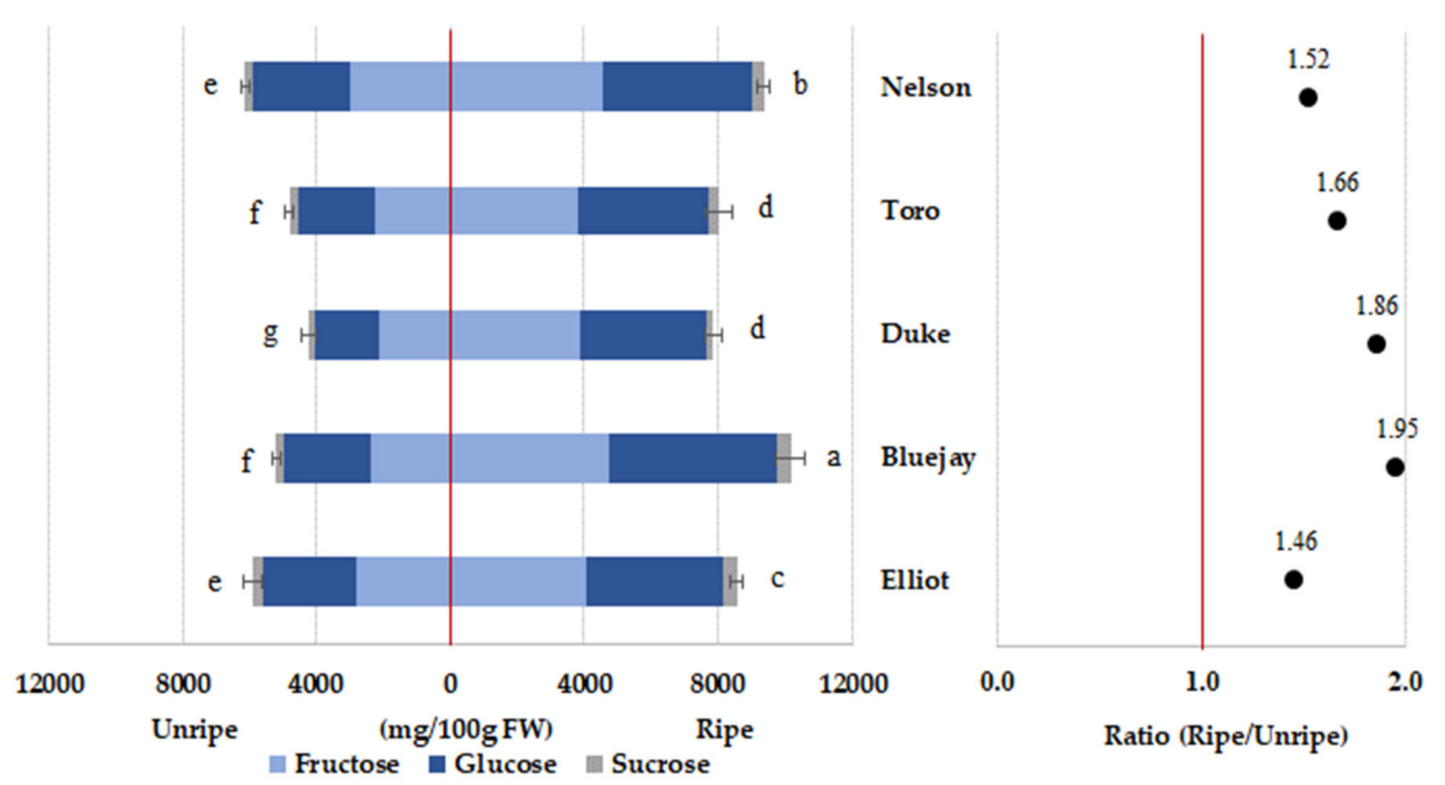

Figure 2. Different letters (a-g) are significant differences by Duncan's multiple range test $(p<0.05)$.

\subsection{Blueberry Total Anthocyanin Content}

The total blueberry fruit anthocyanin content according to cultivar and maturity was significantly higher at the ripe stage than that at the unripe stage in all five cultivars (Table 3). In this study, the blueberry fruit anthocyanin content increased with maturation. Similar findings are also reported by Siriwoharn et al. [31] that the total blackberry anthocyanin of "Marion" and "Evergreen" increases as maturation progresses. Connor et al. [13] reported that the total anthocyanin content in matured "Elliot" was 191-239 mg/100 g FW and Bunea et al. [14] reported that the anthocyanin content in "Elliot" was $163.4 \mathrm{mg} / \mathrm{g}$ FW. These results were higher than our results; the harvest location and the maturity stage at harvest could affect the anthocyanin content. Castrejón et al. [12] reported that total anthocyanin increases as blueberry matures and concludes that anthocyanin biosynthesis is highly related to the developmental stages of the fruit, and enzyme activities are controlled in response to different developmental and environmental cues.

Table 3. Antioxidant content and activities of blueberry fruits at different maturity stages.

\begin{tabular}{|c|c|c|c|c|c|c|}
\hline Cultivars & $\begin{array}{c}\text { Maturity } \\
\text { Stages }\end{array}$ & $\begin{array}{c}\text { Total } \\
\text { Anthocyanins } \\
(\mathrm{mg} / 100 \mathrm{~g})\end{array}$ & $\begin{array}{c}\text { Total } \\
\text { Flavonoids } \\
(\mathrm{mg} \mathrm{CE} / 100 \mathrm{~g})\end{array}$ & $\begin{array}{c}\text { Total } \\
\text { Phenolics } \\
\text { (mg GAE } / 100 \mathrm{~g})\end{array}$ & $\begin{array}{c}\text { DPPH } \\
(\mathrm{mg} / 100 \mathrm{~g})\end{array}$ & $\begin{array}{c}\text { ABTS } \\
(\mathrm{mg} / 100 \mathrm{~g})\end{array}$ \\
\hline Nelson & $\begin{array}{l}\text { Unripe } \\
\text { Ripe }\end{array}$ & $\begin{array}{c}19.67 \pm 0.06^{\mathrm{e}} \\
136.51 \pm 9.95^{\mathrm{ab}}\end{array}$ & $\begin{array}{l}79.83 \pm 6.86^{\mathrm{bc}} \\
102.66 \pm 9.70^{\mathrm{a}}\end{array}$ & $\begin{array}{c}228.51 \pm 3.17^{b} \\
300.90 \pm 12.99^{a}\end{array}$ & $\begin{array}{c}271.69 \pm 11.67^{b c} \\
427.39 \pm 26.16^{a}\end{array}$ & $\begin{array}{c}975.12 \pm 41.90^{\mathrm{d}} \\
1424.10 \pm 102.54 \\
\mathrm{a}\end{array}$ \\
\hline Toro & $\begin{array}{l}\text { Unripe } \\
\text { Ripe }\end{array}$ & $\begin{array}{c}40.28 \pm 1.38^{\mathrm{d}} \\
145.20 \pm 10.13^{\mathrm{a}}\end{array}$ & $\begin{array}{c}66.20 \pm 4.30^{\text {de }} \\
80.94 \pm 2.18^{b}\end{array}$ & $\begin{array}{c}227.66 \pm 5.05^{b} \\
287.33 \pm 13.18^{a}\end{array}$ & $\begin{array}{l}279.75 \pm 9.72^{b c} \\
385.39 \pm 26.83^{a}\end{array}$ & $\begin{array}{c}988.75 \pm 57.41^{\mathrm{d}} \\
1304.22 \pm 60.77^{\mathrm{b}}\end{array}$ \\
\hline Duke & $\begin{array}{l}\text { Unripe } \\
\text { Ripe }\end{array}$ & $\begin{array}{c}28.19 \pm 2.30^{\mathrm{e}} \\
134.76 \pm 8.69^{\mathrm{b}}\end{array}$ & $\begin{array}{c}58.45 \pm 2.30^{\mathrm{e}} \\
71.78 \pm 0.84^{\mathrm{cd}}\end{array}$ & $\begin{array}{l}184.73 \pm 7.67^{\mathrm{d}} \\
242.46 \pm 0.83^{\mathrm{b}}\end{array}$ & $\begin{array}{l}183.01 \pm 66.40^{\text {ef }} \\
322.17 \pm 12.03^{b}\end{array}$ & $\begin{array}{c}830.32 \pm 39.45^{\mathrm{ef}} \\
1176.34 \pm 76.06^{\mathrm{C}}\end{array}$ \\
\hline Bluejay & $\begin{array}{l}\text { Unripe } \\
\text { Ripe }\end{array}$ & $\begin{array}{c}21.81 \pm 2.72 \mathrm{e} \\
137.10 \pm 0.14^{\mathrm{ab}} \\
\end{array}$ & $\begin{array}{l}38.89 \pm 2.53^{\mathrm{f}} \\
67.41 \pm 3.80^{\mathrm{d}}\end{array}$ & $\begin{array}{l}154.80 \pm 0.36^{\mathrm{e}} \\
241.61 \pm 6.49^{\mathrm{b}}\end{array}$ & $\begin{array}{l}151.19 \pm 24.95^{\mathrm{f}} \\
305.20 \pm 1.47^{\mathrm{b}}\end{array}$ & $\begin{array}{c}725.01 \pm 61.02^{\mathrm{f}} \\
1159.88 \pm 84.77^{\mathrm{c}}\end{array}$ \\
\hline Elliot & $\begin{array}{l}\text { Unripe } \\
\text { Ripe }\end{array}$ & $\begin{array}{l}27.39 \pm 2.51^{\mathrm{e}} \\
70.89 \pm 1.64^{\mathrm{c}}\end{array}$ & $\begin{array}{c}42.56 \pm 6.05^{\mathrm{f}} \\
62.93 \pm 2.12^{\mathrm{de}}\end{array}$ & $\begin{array}{c}186.76 \pm 14.67^{\mathrm{d}} \\
203.31 \pm 1.92^{\mathrm{c}}\end{array}$ & $\begin{array}{c}202.11 \pm 29.50^{\mathrm{de}} \\
234.35 \pm 2.65^{\mathrm{cd}}\end{array}$ & $\begin{array}{l}795.06 \pm 93.90 \mathrm{ef} \\
874.04 \pm 40.52 \mathrm{de}\end{array}$ \\
\hline
\end{tabular}

Date are means \pm standard deviation $(\mathrm{mg} / 100 \mathrm{~g}$ fresh weight $(\mathrm{FW})) .{ }^{\mathrm{a}-\mathrm{g}}$ Values in the same column not sharing a common superscript are significantly different by Duncan's multiple range test $(p<0.05)$. 


\subsection{Blueberry Total Flavonoid Content}

The average total flavonoid content of unripe and ripe blueberry fruit was 57.19 and $77.14 \mathrm{mg} / 100 \mathrm{~g} \mathrm{FW}$, respectively. The total flavonoid content of the unripe and ripe "Nelson" cultivar was 79.83 and $102.66 \mathrm{mg} / 100 \mathrm{~g}$ FW, respectively, which was significantly higher than that of the other cultivars. The total flavonoid content of unripe "Bluejay" and 'Elliot' was $38.89 \mathrm{mg} / 100 \mathrm{~g}$ FW and $42.56 \mathrm{mg} / 100 \mathrm{~g}$ FW, respectively, which was significantly lower than that of the other cultivars (Table 3). Studies on the total flavonoid content according to the maturity of berry fruit have been reported. Shin et al. [5] also reported that the flavonoid content is higher in unripe strawberries than in ripe strawberries. Conversely, Hwang et al. [32] reported that the Seolhyang and Maehyang strawberry cultivars showed no significant differences between the unripe and ripe fruit, except for the Janghee cultivar. According to the aronia study, the total flavonoid content of unripe fruit is higher than that of ripe fruit in three cultivars ("Viking", "McKenzie", and "Kingstar K1") [23]. These changes in the flavonoid content in berry fruit, according to maturity, may be due to changes in the content of individual flavonoid compounds, such as quercetin and kaempferol, during ripening [33].

\subsection{Blueberry Total Phenolic Content}

The average phenolic content of unripe and ripe blueberry fruit was 196.49 and $255.12 \mathrm{mg} / 100 \mathrm{~g} \mathrm{FW}$, respectively. The total blueberry phenolic content increased during the ripening process, which was a similar pattern to that of the flavonoid content in this study. Wang et al. [4] reported that the ratio of the total flavonoids to the total phenolics of 14 blueberry cultivars ranges between $18.2 \%$ and $34.2 \%$. In our research, the ratio was $22.8 \%$ to $34.9 \%$, which was similar to their results. The total phenolic content of the "Nelson" and "Toro" cultivars was 300.90 and $287.33 \mathrm{mg} / 100 \mathrm{~g}$ FW in ripe fruit and 228.51 and $227.66 \mathrm{mg} / 100 \mathrm{~g}$ FW in unripe fruit, respectively, which was significantly higher than the other cultivars (Table 3). In the comparison among cultivars according to maturity, the phenolic content was higher at the ripe stage in the order of "Nelson", "Toro", "Duke", "Bluejay", and "Elliot". Connor et al. [13] also reported that total phenolic content in blueberry increases as maturation progresses, and similar results were also reported for Rubus coreanus Miquel and the red raspberry [34,35]. Conversely, Shin et al. [5] reported that unripe "Jewel" strawberries show a higher total phenolic content than ripe fruit, at 300-350 mg (GAE)/100 g FW and 230-280 mg (GAE)/100 g FW, respectively. However, Siriwoharn et al. [31] reported that blackberry phenolic content shows a gradual increase in the "Marion" cultivar as the fruit matures, whereas the "Evergreen" cultivar phenolic content decreases when maturing from the unripe to the half-ripe stage and increases at full ripeness. Thus, the phenolic content in unripe and ripe berry fruit varies according to cultivars and maturity stages.

\subsection{Blueberry Total Antioxidant Activity}

The total antioxidant activities of DPPH and ABTS radical scavenging activity of ripe blueberry were higher than that of unripe fruit, which was a similar pattern to total flavonoids and total phenolics. DPPH radical scavenging activity of ripe "Nelson" and "Toro" cultivars was 427.39 and $385.39 \mathrm{mg} / 100 \mathrm{~g} \mathrm{FW}$, respectively (Table 3). ABTS radical scavenging activity was similar to DPPH radical scavenging activity; ripe "Nelson" showed a value of $1424.10 \mathrm{mg} / 100 \mathrm{~g}$ FW, which was significantly higher than that of other cultivars. Among the unripe fruit, "Nelson" and "Toro" had total antioxidant activities of 975.12 and $988.75 \mathrm{mg} / 100 \mathrm{~g}$ FW, respectively, which was significantly higher than that of the other cultivars (Table 3). Bunea et al. [14] reported that ABTS and DPPH methods are considered to be the most appropriate to measure the antioxidant activity of blueberry fruit, in good agreement with the concentrations of phenolic derivatives (anthocyanins, flavonoids, and polyphenols). Shin et al. [5] reported that Jewel strawberries that are unripe have higher antioxidant activity than fully ripe strawberries. Hwang et al. [32] reported that the total antioxidant activity of ripe and unripe Seolhyang strawberry fruit showed no differences, whereas unripe Janghee fruit showed significantly higher activity than ripe fruit. Yang et al. [23] also reported that antioxidant compounds and activities 
of aronia fruit showed significantly higher values for the unripe stage than the ripe stage. Based on these results, antioxidant activity varies according to cultivar and maturity.

\subsection{Blueberry AChE and BChE Inhibitory Activity Analysis}

A decrease of acetylcholine causes $\mathrm{AD}$, and $\mathrm{AChE}$ is the major enzyme that suppresses acetylcholine levels $[17,18,36]$. The average AChE inhibitory activity of unripe and ripe blueberry extracts $(1 \mathrm{mg} / \mathrm{mL})$ was $77.97 \%$ and $39.69 \%$, respectively. The inhibitory activity was higher at the unripe stage in the order of "Bluejay" (85.19\%), "Nelson" (80.47\%), "Elliot" (77.95\%), "Duke" (76.42\%), and "Toro" (69.84\%) (Figure 3). The average BChE inhibitory activity of unripe and ripe blueberry extracts $(1 \mathrm{mg} / \mathrm{mL})$ was $77.09 \%$ and $20.68 \%$, respectively. The average inhibitory activity rate (\%) of unripe fruit was approximately 3.7 times higher than that of ripe fruit (Figure 4). Currently, only a few studies on the AChE inhibitory activity of berry fruit have been reported. Hwang et al. [32] reported that unripe strawberries showed a significantly higher AChE inhibition rate than the ripe fruit. A study on the AChE inhibition activity has also been attempted in medicinal plants. According to Jung et al. [19], Schisandra chinensis, Hovenia dulcis, Thuja orientalis, and Eleutherococcus senticosus showed relatively high AChE inhibitory activities at $1 \mathrm{mg} / \mathrm{mL}$ final concentration, which were $33.0 \%, 26.6 \%, 20.7 \%$, and $17.8 \%$, respectively. Extracts of Angelica gigas, Polygala tenuifolia, Cnidium officinale, Poria cocos, and Acorus gramineus showed approximately $6 \%-10 \%$ inhibitory activity.

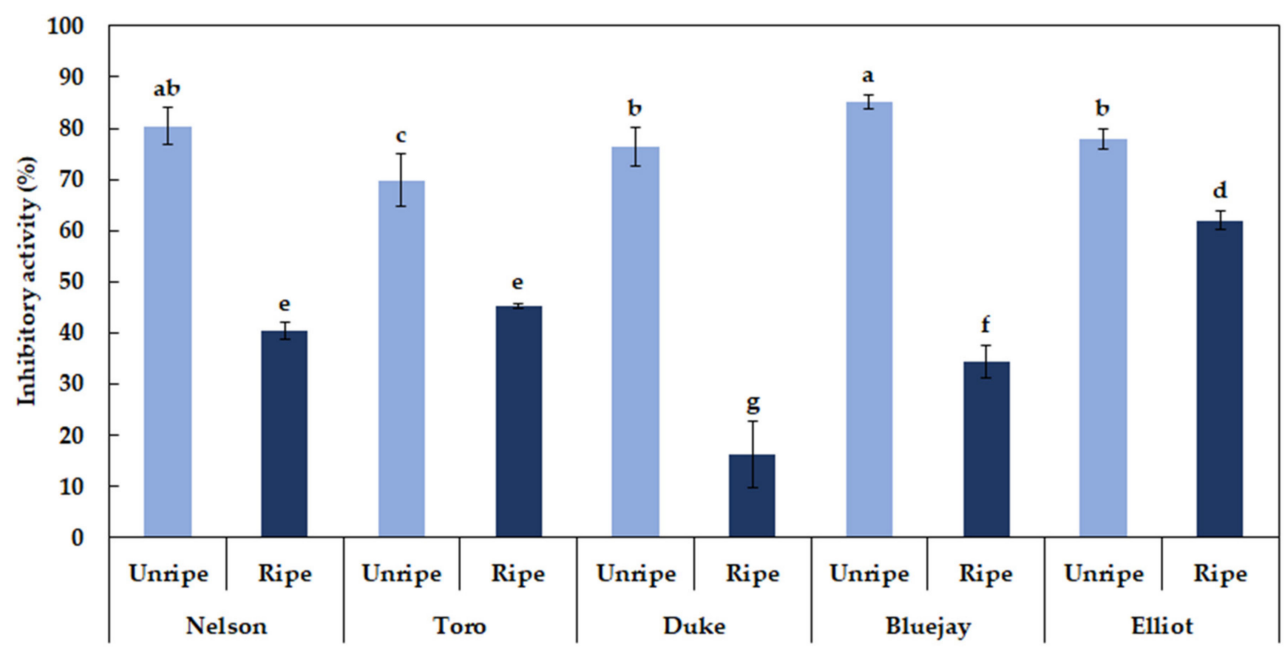

Figure 3. Different letters (a-g) are significant differences by Duncan's multiple range test $(p<0.05)$.

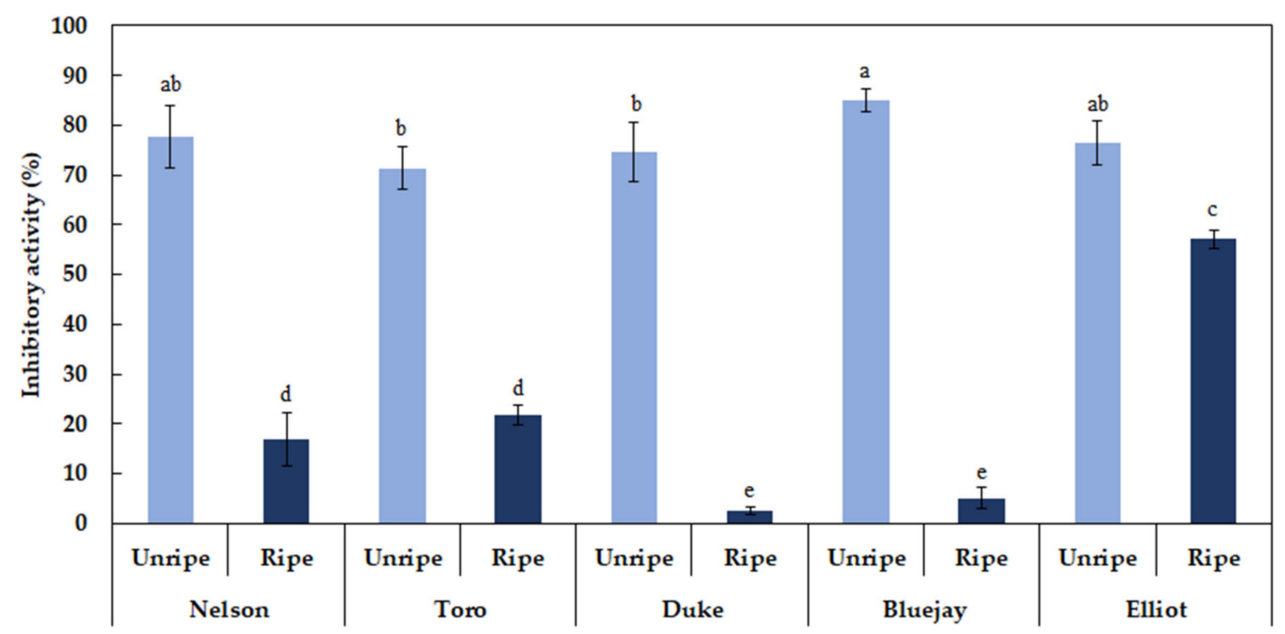

Figure 4. Different letters (a-e) are significant differences by Duncan's multiple range test $(p<0.05)$. 


\subsection{Blueberry Correlation between Blueberry Antioxidant Content and Activity}

Pearson correlations were used to determine the relationship between antioxidant compounds and activity (Table 4). Among the blueberry cultivars, the total phenolic content was highly correlated to the DPPH and ABTS radical scavenging activity by $\mathrm{R}=0.974$ and 0.964 , respectively. The total blueberry phenolic content was also strongly correlated with total flavonoid content $(R=0.903)$. Bunea et al. [14] reported that the ferric reducing antioxidant power (FRAP), ABTS, and DPPH assays are highly significantly correlated; moreover, total polyphenol content and total anthocyanin content in blueberries also showed strong correlations. Further, Shin et al. [5] reported that the total antioxidant activity of strawberry is highly correlated with total flavonoids and phenolics and that the relationships between total phenolics and flavonoids are also strong, which agree with the results of the present study. However, the relationship between total antioxidant activities measured using the DPPH and ABTS methods was strong $(\mathrm{R}=0.956)$; the total flavonoid content was highly correlated with DPPH and ABTS radical scavenging activity, $\mathrm{R}=0.882$ and 0.857 , respectively, but not with the AChE $(\mathrm{R}=-0.542)$ or BChE $(\mathrm{R}=-0.597)$ inhibitory activities. Several studies have reported that the total phenolic concentrations of fruits are positively related to the total antioxidant activity $[4,5,23,32]$. The relationships between the total antioxidant activity and the AChE or BChE inhibitory activity are negative in this study because the unripe fruits showed higher cholinesterase inhibitory activity than ripe fruits.

Table 4. Pearson correlation $(R)$ between antioxidant compounds, antioxidant activities, and AChE and BChE inhibitory activity of blueberry fruits.

\begin{tabular}{|c|c|c|c|c|c|c|}
\hline & Total Anthocyanins & Total Flavonoids & Total Phenolics & DPPH & ABTS & AChE \\
\hline $\begin{array}{c}\text { Total } \\
\text { flavonoids }\end{array}$ & $0.621^{* *}$ & & & & & \\
\hline $\begin{array}{c}\text { Total } \\
\text { phenolics }\end{array}$ & $0.801^{* *}$ & $0.903^{* *}$ & & & & \\
\hline DPPH & $0.806^{* *}$ & $0.882 * *$ & $0.974^{* *}$ & & & \\
\hline ABTS & $0.859 * *$ & $0.857^{* *}$ & $0.964^{* *}$ & $0.956^{* *}$ & & \\
\hline $\mathrm{AChE}$ & $-0.928^{* *}$ & $-0.542^{* *}$ & $-0.685^{* *}$ & $-0.714^{* *}$ & $-0.770 * *$ & \\
\hline BChE & $-0.969 * *$ & $-0.597^{* *}$ & $-0.748 * *$ & $-0.768^{* *}$ & $-0.825^{* *}$ & $0.972 * *$ \\
\hline
\end{tabular}

\section{Conclusions}

In the present study, physicochemical properties, antioxidant compounds, antioxidant activities, and $\mathrm{AChE}$ and BChE inhibition activities of five blueberry cultivars harvested at different ripening stages were investigated. The results showed that total phenolic, flavonoid, anthocyanin content, and antioxidant activity were higher in ripe blueberries than in unripe fruit. On the contrary, the AChE and BChE inhibitory activities were higher at the unripe stage. This study is highly significant because only a few studies on the AChE inhibitory activity of berry fruit have been reported so far. Among the blueberry cultivars, the total phenolic content was highly correlated to the DPPH and ABTS radical scavenging activity. The total blueberry phenolic content was also strongly correlated with total flavonoid content. Although the ripe blueberry fruits contain comparatively more abundant antioxidative effects and higher SSC/TA ratios than the unripe fruits, the unripe blueberries show a high cholinesterase inhibitory activity, and they could use as a potential promising ingredient for developing functional foods.

Author Contributions: Conceptualization, Y.-J.K. and Y.S.; methodology, H.H., Y.-J.K., and Y.S.; formal analysis, H.H., Y.-J.K., and Y.S.; writing-original draft preparation, H.H.; writing-review and editing, Y.-J.K. and Y.S. All authors have read and agreed to the published version of the manuscript.

Funding: The present research was conducted by the research fund of Dankook University in 2019.

Conflicts of Interest: The authors declare no conflict of interest. 


\section{References}

1. Koss-Mikołajczyk, I.; Kusznierewicz, B.; Bartoszek, A. The relationship between phytochemical composition and biological activities of differently pigmented varieties of berry fruits; comparison between embedded in food matrix and isolated anthocyanins. Foods 2019, 8, 646. [CrossRef] [PubMed]

2. Di Gioia, F.; Tzortzakis, N.; Rouphael, Y.; Kyriacou, M.C.; Sampaio, S.L.; Ferreira, I.C.; Petropoulos, S.A. Grown to be blue-Antioxidant properties and health effects of colored vegetables. Part II: Leafy, fruit, and other vegetables. Antioxidants 2020, 9, 97. [CrossRef] [PubMed]

3. Mao, Q.Q.; Xu, X.Y.; Shang, A.; Gan, R.Y.; Wu, D.T.; Atanasov, A.G.; Li, H.B. Phytochemicals for the prevention and treatment of gastric cancer: Effects and mechanisms. Int. J. Mol. Sci. 2020, 21, 570. [CrossRef] [PubMed]

4. Wang, H.; Guo, X.; Hu, X.; Li, T.; Fu, X.; Liu, R.H. Comparison of phytochemical profiles, antioxidant and cellular antioxidant activities of different varieties of blueberry (Vaccinium spp.). Food Chem. 2017, 217, 773-781. [CrossRef]

5. Shin, Y.; Ryu, J.A.; Liu, R.H.; Nock, J.F.; Watkins, C.B. Harvest maturity, storage temperature and relative humidity affect fruit quality, antioxidant contents and activity, and inhibition of cell proliferation of strawberry fruit. Postharvest Biol. Technol. 2008, 49, 201-209. [CrossRef]

6. Aqil, F.; Jeyabalan, J.; Kausar, H.; Munagala, R.; Singh, I.P.; Gupta, R. Lung cancer inhibitory activity of dietary berries and berry polyphenolics. J. Berry Res. 2016, 6, 105-114. [CrossRef]

7. Lucioli, S.; Pastorino, F.; Nota, P.; Ballan, G.; Frattarelli, A.; Fabbri, A.; Forni, C.; Caboni, E. Extracts from cell suspension cultures of strawberry (Fragaria x ananassa Duch): Cytotoxic effects on human cancer cells. Molecules 2019, 24, 1738. [CrossRef]

8. Joseph, S.V.; Edirisinghe, I.; Burton-Freeman, B.M. Berries: Anti-inflammatory effects in humans. J. Agric. Food Chem. 2014, 62, 3886-3903. [CrossRef]

9. Manganaris, G.A.; Goulas, V.; Vicente, A.R.; Terry, L.A. Berry antioxidants: Small fruits providing large benefits. J. Sci. Food Agric. 2014, 94, 825-833. [CrossRef]

10. Aldridge, R.B.; Jennings, K.M.; Chaudhari, S.; Monks, D.W.; Everman, W.J.; Mehra, L.K. Tolerance of southern highbush and rabbiteye blueberry cultivars to saflufenacil. Weed Technol. 2019, 33, 475-480. [CrossRef]

11. Kim, T.C.; Bae, K.S.; Kim, I.K.; Chun, H.J. Antioxidative activities of solvent extracts from blueberry. Korean J. Orient. Physiol. Pathol. 2005, 19, 179-183.

12. Castrejón, A.D.R.; Eichholz, I.; Rohn, S.; Kroh, L.W.; Huyskens-Keil, S. Phenolic profile and antioxidant activity of highbush blueberry (Vaccinium corymbosum L.) during fruit maturation and ripening. Food Chem. 2008, 109, 564-572. [CrossRef]

13. Connor, A.M.; Luby, J.J.; Hancock, J.F.; Berkheimer, S.; Hanson, E.J. Changes in fruit antioxidant activity among blueberry cultivars during cold-temperature storage. J. Agric. Food Chem. 2002, 50, 893-898. [CrossRef] [PubMed]

14. Bunea, A.; Rugina, O.D.; Pintea, A.M.; Sconta, Z.; Bunea, C.I.; Socaciu, C. Comparative polyphenolic content and antioxidant activities of some wild and cultivated blueberries from Romania. Not. Bot. Hor. Agrobot. 2011, 39, 70-76. [CrossRef]

15. Jeong, C.H.; Choi, S.G.; Heo, H.J. Analysis of nutritional compositions and antioxidative activities of Korean commercial blueberry and raspberry. J. Korean Soc. Food Sci. Nutr. 2008, 37, 1375-1381. [CrossRef]

16. Singh, M.; Arseneault, M.; Sanderson, T.; Murthy, V.; Ramassamy, C. Challenges for research on polyphenols from foods in Alzheimer's disease: Bioavailability, metabolism, and cellular and molecular mechanisms. J. Agric. Food Chem. 2008, 56, 4855-4873. [CrossRef]

17. Adsersen, A.; Kjølbye, A.; Dall, O.; Jäger, A.K. Acetylcholinesterase and butyrylcholinesterase inhibitory compounds from Corydalis cava Schweigg. \& Kort. J. Ethnopharmacol. 2007, 113, 179-182.

18. Orhan, I.; Sener, B.; Choudhary, M.I.; Khalid, A. Acetylcholinesterase and butyrylcholinesterase inhibitory activity of some Turkish medicinal plants. J. Ethnopharmacol. 2004, 91, 57-60. [CrossRef]

19. Jung, Y.S.; Park, S.J.; Kim, J.E.; Yang, S.A.; Park, J.H.; Kim, J.H. A comparative study of GABA, glutamate contents, acetylcholinesterase inhibition and antiradical activity of the methanolic extracts from 10 edible plants. Korean J. Food Sci. Technol. 2012, 44, 447-451. [CrossRef]

20. Kim, Y.J.; Shin, Y. Antioxidant profile, antioxidant activity, and physicochemical characteristics of strawberries from different cultivars and harvest locations. J. Korean Soc. Appl. Biol. Chem. 2015, 58, 587-595. [CrossRef] 
21. Boyles, M.J.; Wrolstad, R.E. Anthocyanin composition of red raspberry juice: Influences of cultivar, processing, and environmental factors. J. Food Sci. 1993, 58, 1135-1141. [CrossRef]

22. Zulkifli, S.A.; Abd Gani, S.S.; Zaidan, U.H.; Halmi, M.I.E. Optimization of total phenolic and flavonoid contents of defatted pitaya (Hylocereus polyrhizus) seed extract and its antioxidant properties. Molecules 2020, 25, 787. [CrossRef] [PubMed]

23. Yang, H.; Kim, Y.J.; Shin, Y. Influence of ripening stage and cultivar on physicochemical properties and antioxidant compositions of aronia grown in South Korea. Foods 2019, 8, 598. [CrossRef] [PubMed]

24. Aryal, S.; Baniya, M.K.; Danekhu, K.; Kunwar, P.; Gurung, R.; Koirala, N. Total phenolic content, flavonoid content and antioxidant potential of wild vegetables from western Nepal. Plants 2019, 8, 96. [CrossRef]

25. Mira-Sánchez, M.D.; Castillo-Sánchez, J.; Morillas-Ruiz, J.M. Comparative study of rosemary extracts and several synthetic and natural food antioxidants. Relevance of carnosic acid/carnosol ratio. Food Chem. 2020, 309, 125688. [CrossRef]

26. Sridhar, K.; Charles, A.L. In vitro antioxidant activity of Kyoho grape extracts in DPPH and ABTS assays: Estimation methods for EC50 using advanced statistical programs. Food Chem. 2019, 275, 41-49. [CrossRef]

27. Ellman, G.L.; Courtney, K.D.; Andres, V., Jr.; Featherstone, R.M. A new and rapid colorimetric determination of acetylcholinesterase activity. Biochem. Pharmacol. 1961, 7, 88-95. [CrossRef]

28. Harker, F.R.; Stec, M.G.; Hallett, I.C.; Bennett, C.L. Texture of parenchymatous plant tissue: A comparison between tensile and other instrumental Watkins and sensory measurements of tissue strength and juiciness. Postharvest Biol. Technol. 1997, 11, 63-72. [CrossRef]

29. Forney, C.F.; Kalt, W.; Jordan, M.A.; Vinqvist-Tymchuk, M.R.; Fillmore, S.A. Blueberry and cranberry fruit composition during development. J. Berry Res. 2012, 2, 169-177. [CrossRef]

30. Li, X.; Li, C.; Sun, J.; Jackson, A. Dynamic changes of enzymes involved in sugar and organic acid level modification during blueberry fruit maturation. Food Chem. 2020, 309, 125647. [CrossRef]

31. Siriwoharn, T.; Wrolstad, R.E.; Finn, C.E.; Pereira, C.B. Influence of cultivar, maturity, and sampling on blackberry (Rubus L. Hybrids) anthocyanins, polyphenolics, and antioxidant properties. J. Ag. Food Chem. 2004, 52, 8021-8030. [CrossRef]

32. Hwang, H.; Shin, Y.; Kim, Y.J. Influence of ripening stage and cultivar on physicochemical properties, sugar and organic acid profiles, and antioxidant compositions of strawberries. Food Sci. Biotechnol. 2019, 28, 1659-1667. [CrossRef] [PubMed]

33. Wang, S.Y.; Chen, C.T.; Wang, C.Y. The influence of light and maturity on fruits quality and flavonoid content of red raspberries. Food Chem. 2009, 112, 676-684. [CrossRef]

34. Cha, H.S.; Youn, A.R.; Park, P.J.; Choi, H.R.; Kim, B.S. Comparison of physiological activities of Rubus coreanus Miquel during maturation. J. Korean Soc. Food Sci. Nutr. 2007, 36, 680-688. [CrossRef]

35. Wang, Y.S.; Lin, H.S. Antioxidant activity in fruits and leaves of blackberry, raspberry, and strawberry varies with cultivar and developmental stage. J. Agric. Food Chem. 2000, 48, 140-146. [CrossRef]

36. Bui, T.T.; Nguyen, T.H. Natural product for the treatment of Alzheimer's disease. J. Basic Clin. Physiol. Pharmacol. 2017, 28, 413-423. [CrossRef]

(C) 2020 by the authors. Licensee MDPI, Basel, Switzerland. This article is an open access article distributed under the terms and conditions of the Creative Commons Attribution (CC BY) license (http://creativecommons.org/licenses/by/4.0/). 